Journal of Maternal and Child Health (2016), 1(1): 34-40

https://doi.org/10.26911/thejmch.2016.01.01.06

\title{
Analysis of Factors Affecting Childbirth with Caesarean in Kediri, Indonesia
}

\author{
Dian Rahmawati'), Didik Tamtomo²), Uki Retno Budihastuti3) \\ 1)Masters Program of Public Health, Sebelas Maret University, Surakarta \\ 2)Faculty of Medicine, Sebelas Maret University, Surakarta \\ 3)Department of Obstetrics and Gynecology, Dr. Moewardi Hospital, Surakarta
}

\begin{abstract}
Background: Cesarean section has a maternal mortality risk 4 times higher than those with normal birth. In Kediri, the incidence of cesarean section increased, i.e. 8.5\% in 2012 to $15.3 \%$ in 2015. Therefore, this study aimed to analyze the factors affecting cesarean section deliveries in Kediri.

Subjects and Method: This was an observational analytical study with case control design. A total sample of 50 women giving birth with cesarean section and 50 normal birth. The population was all women giving birth by cesarean section in Kediri. A sampling technique was using a Fixed Sampling Disease. Data analysis used multiple logistic regression.

Results: Maternal age $<20$ or $\geq 35$ years was lower the chances of having cesarean 0.83 times compared to mothers aged 20-35 years and was not statistically significant $(\mathrm{OR}=0.83 ; 95 \% \mathrm{CI}=$ $0: 26$ to $2.78, \mathrm{p}=0.757$ ), Parity 1 and $\geq 4$ increase of 1.64 times more likely to undergo cesarean section than parity $2-3$ and was not statistically significant $(\mathrm{OR}=1.64 ; 95 \% \mathrm{CI}=0.60$ to $4: 58$, $\mathrm{p}=0341)$. Less physical activity during pregnancy increases the likelihood of cesarean section 1:10 of times and was not statistically significant $(\mathrm{OR}=1: 10$; CI $95 \%=0: 38$ to $2.90, \mathrm{p}=0932)$. Mothers who experienced complications during labor increases the risk 12 times through cesarean section and was statistically significant $(\mathrm{OR}=12 ; 95 \% \mathrm{CI}=3.56$ to $41.81, \mathrm{p}<0.001)$. Mothers who do their own request for delivery by cesarean section increases the likelihood 21 times through cesarean section and was statistically significant $(\mathrm{OR}=21: 24 ; 95 \% \mathrm{CI}=5.22$ to $86.33, \mathrm{p}<0.001)$.

Conclusion: There is a positive correlation, very strong and statistically significant between the complications of labor and delivery at hisown request by cesarean section.
\end{abstract}

Keywords: cesarean section, affecting factors

\section{Correspondence:}

Dian Rahmawati. School of Public Health, Sebelas Maret University, Jl. Ir. Sutami 36 A, Surakarta 57126, Central Java. Email: lintangkayana31@gmail.com.

\begin{tabular}{l}
\hline BACKGROUND \\
\hline Even though MDGs has ended, but the \\
numbers Maternal Mortality Rate (MMR) \\
in many developing countries including \\
Indonesia is still high. MMR in Indonesia \\
is on the $51^{\text {st }}$ of 257 countries worldwide. \\
While, according to SDKI 2012, MMR in \\
Indonesia jumped from the previous year, \\
i.e. 228 of 100, ooo life birth and in 2012 \\
359 of 100,00o life birth (Indonesian \\
Health Ministry, 2014). The major cause of \\
maternal deaths are mainly difficulties and
\end{tabular}

complications during childbirth that cause further action to be action to be taken when normal childbirth is not possible, that is vacuum extraction and cesarian section (Manuaba et al., 2010).

According to SDKI 2007, the number of cesarean section in Indonesia is $22.8 \%$. It increases to 29.6\% in 2009 (Afriani 2013). Based on the data from Dinkes Kediri, the number of cesarean section is $8.5 \%$ in 2012 and it becomes $14.3 \%$ in 2015 . 
Cesarean section also holds a bigger risk, that is 4 times more dangerous than normal childbirth. The main causes of maternal deaths in cesarean section are bleeding, post-delivery infection, and thromboembolism. Other risks that may also happen are post-surgery infection, delay in breastfeeding due to anesthetic and post-surgery pain, womb rupture risk, fetal growth outside the womb on the pregnancy, or ectopic pregnancy (Sibuea, 2007). In the event of the risks imposed, cesarean section must be considered in accordance to risk factors. The purpose of this research was to analyze the factors that influence cesarean section in Kediri.

\section{SUBJECTS AND METHOD}

This research type was observational analysis with case control approach. The research was done in RS Aura Syifa, RSUD Gambiran, and RSIA Melinda in April 2016. The population of this research was all mothers giving birth by cesarean section in Kediri. By using Fixed Disease Sampling, 100 sample subjects was gathered. It consisted of 50 normal childbirth as the control group and 50 cesarean section childbirth. The variables of this research consisted of dependent variables (cesarean section childbirths), and independent variables (mothers' age, parity, mother's physical activities during pregnancy, and own request.)

The measuring intrument used was Baecke's applied questionnaire to determine the variables' physical activities during pregnancy (Baecke et al., 1982) and doctor's diagnoses on the patient's medical records. Data analysis done by univariate, bivariate with Chi Square $\left(\mathrm{X}^{2}\right)$ test, and multivariate analysis with multiple regression logistic test. Odds Ratio (OR) statistic was analyzed by Wald test (Murti B, 2013).

\section{RESULTS}

Mother's age $<20$ or $\geq 35$ years old reduces the possibility of undergoing cesarean section by 0.83 times than mothers 20-35 years old and statistically insignificant $(\rho$ $=0.757)$. Parity of 1 and $\geq 4$ increases the possibility of undergoing cesarean section by 1.64 times than parity 2-3 and statistically insignificant $(\mathrm{p}=0.341)$.

Table 1. The result of analyzing multiple logistic regression regarding the factors affecting cesarean section in Kediri

\begin{tabular}{lrccc}
\multicolumn{1}{c}{ Variables } & \multirow{2}{*}{ OR } & \multicolumn{2}{c}{ CI 95\% } & \multirow{2}{*}{ p } \\
\cline { 3 - 4 } & & Lower limit & Upper limit & \\
\hline Mothers' age $(<20,>35$ years old) & 0.83 & 0.26 & 2.78 & 0.757 \\
Parity $(1, \geq 4)$ & 1.64 & 0.60 & 4.58 & 0.341 \\
Lack of physical activities during pregnancy & 1.10 & 0.38 & 2.90 & 0.932 \\
Childbirth difficulties factor finding & 12 & 3.53 & 40.81 & $<0.001$ \\
Personal request & 21.24 & 5.22 & 86.33 & $<0.001$ \\
N observasi $=100$ & & & & \\
Nagelkerke $\mathrm{R}^{2}=47.5 \%$ & & & \\
Hosmer and Lameshow Test $\rho=0.859$ & & & \\
\hline
\end{tabular}

The lack of physical activities during pregnancy increases the possibility of cesarean section by 1.10 times compared to those having enough activities and statistically insignificant $(\mathrm{p}=0.932)$. Mothers who had complications increases the risk to undergo cesarean section by 12 times compared to those who didn't have the same problem and it is statiscally significant $(\mathrm{p}<0.001)$. Mothers who requested the cesarean section increased by 21 times and it is statiscally significant. 


\section{DISCUSSION}

Mothers' age $<20$ or $\geq 35$ years old lowers the possibility of having cesarean section by o.83 times than mothers of 20-35 years old and it was statistically insignificant $(\mathrm{OR}=$ 0.83 ; CI $95 \%=0.26$ to $2.78, \mathrm{p}=0.757$ ). Mothers age 20-35 years old actually increased the risk of taking cesarean. This is against the theori saying that the safest age for getting pregnant and giving birth is around 20-35 years old and unsafe age is $<20$ years old or $\geq 35$ years old (Wiknjosastro, 2007).

This research is in accordance with the research done by Mursalim et al., (2012) and Khotijah et al., (2014) that cesarean section happens more on mothers of 20-35 years of age compared to those age $<20$ or $\geq 35$ years old. Group age 20-35 years old are the safest age for giving birth by there are also other factors i.e. $3 \mathrm{P}$ (power, pasenger, passage) that connects with the childbirth and its complications. The risk factors more often becomes the cause of childbirth difficulties thus why cesarean section considered as the best way to deliver the fetus. The childbirth difficulties that comes up such as preeclampsia, csection history, breech fetus, premature rupture of membranes, long labor, CPD, and mother's psychological condition.

Parity 1 and $\geq 4$ increased the possibility by 1.64 times to undergo cesarean section more than those parity 2-3 and statistically insignificant (OR=1.64; CI 95\%= 0.60 to $4.58, \mathrm{p}=0.341$ ). This is in accordance to the research done by Mursalim et al., (2012) and Yudiyah (2013) that parity is not connected to the possibility of cesarean section but parity 1 and $\geq 4$ increases the possibility of undergoing the procedure. Besides that, parity 1 and $\geq 4$ increases the risk of maternal fatality due to the maturity and the decreasing of the mothers' reproductive organs. The presence of childbirth difficulties caused multipara (paritas $\geq 4$ ) childbirth with cesarean section.

According to Wiknjosastro (2007) on parity $\geq 4$ the uterus will loosen and it will cause the abnormality of the fetal and placenta position. Such events could result in complications that would contribute in the childbirth difficulties and becomes indication of cesarean section. On the first pregnancy, the mothers' childbirth passage is not yet tested and on pregnancy $\geq 4$ a woman's reproductive system is already declining.

Lack of physical activities during pregnancy increased the possibility by 1.10 times compared to those having enough activities during pregnancy and it is statistically insignificant (OR=1.10; 95\% CI $=0.38$ to $2.90, p=0.932$ ). Weight gaining during pregnancy makes it difficult for a pregnant mother to move and be active. This makes pregnant mothers have the tendency to be lazy and use more of their time to rest and relax. Pregnant mothers who are lazy may have difficulties in childbirth. A lot of researches reported that women who kept on being active while pregnant experienced shorter childbirth compared those who relaxes more. Physical activities during pregnancy also brings positive impact on ripening the cervix prechildbirth thus avoiding long partus. Besides that, physical activities also helps reducing medical intervention during childbirth for example amniotomi, childbirth induction, or even cesarean section (Szumilewicz et al., 2013).

This is in accordance to the the research done by Jayakody and Senanayake (2015); Domenjoz et al., (2014); Leon et al., (2015) that cesarean section significantly connected to the patient's physical activities during pregnancy $(\mathrm{p}=0.015)$. Pregnant mothers who does not have enough physic- 
cal activities pose larger risk in taking cesarean section.

Physical and mental preparation followed by physical exercise (Lamaze exercise) is very useful for pregnant mothers to eliminate fear and anxiety experienced by them. The physical exercises (Lamaze exercise) to flex pelvic and abdominal muscles and psychologically, Lamaze exercise help increasing the mother's confidence when in labour (Chuntharapat et al., 2008).

Childbirth with complications increased the risk of cesarean section by 12 times compared to those with no complications and it is statistically significant $(\mathrm{OR}=12$; 95\% $\mathrm{CI}=93.56$ to $41.81, \mathrm{p}<0.001)$. Complications during childbirth are among others cephalo pelvic disproportion (5.62\%), postdate $(6.74 \%)$, preeclampsia $(16.85 \%)$, long partus $(7.89 \%)$, premature rupture of membranes (10.11\%), fetal breech (11.24\%), and previous c-section history (14.61\%).

CPD is a condition where the fetus is unable to go through the pelvic. This happen when the fetus head is larger than the mother's pelvic or normal pelvic but large fetus. Cesarean section is done to mothers with CPD to avoid more dangerous impact that would endanger the lives of both the mother and the fetus such as uterus rupture, fistula due to the length period when the baby pushed the passage for too long, intrapartum infection, funikuly prolaps, and even brain damage that would be fatal for the fetus (Prawirohardjo, 2009). Postdate is one of high risk pregnancy, where the level of oxytocin drops thus causing his and delay in childbirth, and the placenta is not able to deliver the much needed protein and $\mathrm{CO}_{2} / \mathrm{O}_{2}$ exchange risking the fetus from asphyxia to death inside the womb (Manuaba et al., 2007).

Long partus is when the childbirth process takes more than 24 hours. Long partus may cause exhaustion to the mother, infection, and bleeding due to uteri atonia, uteri rupture, or birth passage laseration. In long partus, fetal distress may also happen because of there is disturbance in the supply of oxyven and blood from the mother to the fetus. Lack of oxygen will cause fetal asphyxia. In long partus with premature rupture of membranes, the risk of infection is higher. Cesarean section is considered to reduce the risk of morbidity and mortality for both mother and fetus (Hinelo et al., 2013).

Premature amniotic membrane rupture is when the amniotic membrane is ruptured spontaneously one hour before the delivery. Andayasari et al., (2014) research showed that cesarean deliveries with premature amniotic membranes is $\mathbf{2 . 5}$ time more risk in taking cesarean section. Premature amniotic membrane rupture often cause infection thus faster medical intervention is needed to avoid the risk of maternal and perinatal morbidity and mortality.

The cause of fetal breech is not known but it may due to the fetus ability to move freely inside the womb for example in such cases like preterm babies, placenta previa, hidramnion, gemeli, and other fetal cranial abnormality. If pre-vaginam delivery is chosen, the process would take much longer because the head would not function as cervical width dilatation. Laseration, rupture, and wider episiotomy would also be needed. The umbilical cord would experience prolap. The fetus also risk having intra-cranial bleeding, medula spinalis injury caused by childbirth manipulation and stretching, palsi brachial plexus, and arm fracture. Considering the higher risk, cesarean section is needed in fetal breech presentation (Olam dan Floranita, 2013).

Previous cesarean section history for patients that had undergone the procedure on her previous pregnancy or cervical 
surgery (for example miomectomy). Uteri rupture risk is the main consideration in making the decision to take another cesarean section for the next pregnancy (Hamilton, 2004).

The most childbirth complication in this research is preeclampsia. Preeclampsia is a condition where hypertension with urine protein and edema after 20 weeks old pregnancy or right after delivery. Preeclampsia diagnoses is based one two of three factors, i.e. excessive weight gain, edema, hypertension, and urine protein Wiknjosastro, 2007). This research is in accordance with the research done by Andayasari et al., (2014) that preeclampsia or eclampsia has bahwa times risk in undergoing cesarean section. Preeclampsia or eclampsia is a risk factor in maternal and fetal deaths. From result of a research done in RS Dr. Moewardi, Surakarta in 2014, the $54 \%$ rate of maternal and fetal mortality due to cesarean section is mainly due to preeclampsia (Andayasari et al., 2014).

Section done by personal request had 21 times more risk in cesarean section than those done by medical indication and it is statistically significant (OR=21.24; CI 95\% $=5.22$ to 86.33, $\mathrm{p}<0.001)$. This is in accordance with the research done by Salfariani and Nasution (2012) that besides complication in pregnancy, the decision to undergo cesarean section is at times taken by irrational reasoning, that is without any complication and based on the patient's request. The choosing factor on this request is usually from the husband and family, mother's lack of knowledge, anxiety in facing normal childbirth, and trust.

The husband's role and advice is mostly because of safety reason and practical reason from having to wait long for the delivery process and the worries of the wife's screaming in pain and fear of something might happen to the baby if normal childbirth is taken instead (Sarmana, 2004). Mother's knowledge in the childbirth process is very important because it would affect on the treatment while pregnant and making decision for delivery later. The increasing tendency in taking cesarean section connects to the increasing level of their attention to their own pregnancy (Kasdu, 2003).

Anxiety to normal childbirth also affecting the decision taken when choosing cesarean section by personal request. This is in accordance with the research done by Sarmana (2004) that mothers choose cesarean section because they are afraid of the pain caused by normal childbirths. Other factors are the believe of certain day and time of delivery. According to Kasdu (2003) cesarean section also done because the belief that connects the time of child birth and the luck and fate of the child hoping that a child born at a certain time and date will have more luck and better life.

From this research, we can conclude that there was a strong positive relationship and statistically significant between childbirth complications and personal request in cesarean section. For pregnant and delivering mothers, they need to undergo regular checkup to the medical workers to detect the possible complications that may occur during pregnancy and in delivery. Medical workers have to provide counseling for pregnant mothers in explaining the benefit and disadvantage in taking cesarean section for pregnant and delivering mothers.

\section{REFERENCE}

Afriani A, Desmiwarti, Kadri H (2013). Kasus persalinan dengan bekas seksio sesarea menurut keadaan waktu masuk di bagian obstetri dan ginekologi RSUP Dr. M. Djamil Padang. Jurnal Kesehatan Andalas 2(3). 
Andayasari L, Muljati S, Sihombing M, Arlinda D, Opitasari C, Mogsa DF, Widianto (2014). The proportion of caesarean section and associated factors in hospital of Jakarta. Buletin Penelitian Kesehatan, 43(2): 105-116.

Baecke JA, Burema J, Frijters JE (1982). A short questionnaire for the measurement of habitual physical activity in epidemiological studies. The American Journal of Clinical Nutrition, 36: 936-942.

Chuntharapat S, Petpichetchian W, Hatthakit U (2008). Effects of Yoga on Maternal Comfort, Labour Pain and Birth Outcomes. Comlementary Therapies in Clinical Practice. 105-115.

Domenjoz I, Kayser B, Boulvain M (2014). Effect of physical activity during pregnancy on mode of delivery. American Journal Obstetrics and Gynecology 211: 401.e1-11.

Hamilton PM (2004). Dasar-dasar keperawatan maternitas edisi 6 revisi. Jakarta: EGC.

Hinelo F, Suparman E, Tendean H (2013). Luaran Partus Lama di BLU RSU Prof. DR. R. D. Kandou Manado. Jurnal e-Biomedik (eBM) 1(1) : 101-105.

Jayakody O, Senanayake H (2015). Effect of Physical Activity During Pregnancy on Birth Outcomes in Mothers Presenting at the Antenatal Clinic of De Soysa Maternity Hospital, Colombo 08. Asia Pacific Journal of Multidisciplinary Research 3(2).

Kasdu, Dini (2003). Operasi Caesar Masalah dan Solusinya. Jakarta: Puspa Swara.

Kementrian Kesehatan RI (2014). Mothers day, situasi kesehatan ibu. Jakarta: Pusat Data dan Informasi Kementrian Kesehatan RI/InfoDATIN

Khotijah, Anasari T, Khosidah A (2014). Hubungan usia dan paritas dengan kejadian retensio plasenta pada ibu bersalin. Bidan Prada : Jurnal Ilmiah Kebidanan, 5(1): 27-32.

Leon RP, Hermoso AG, Martinez GS, Bueno CA, Lopez MS, Vizcaino VM (2015). Effects of exercise during pregnancy on mode of delivery: a meta-analysis. Acta Obstetrics Gynecology Scand, 94(10):1039-47.

Manuaba IBG, Manuaba IAC, Manuaba IBGF (2007). Pengantar kuliah obstetri. Jakarta : EGC.

Manuaba IBG, Manuaba IAC, Manuaba IBGF (2010). Ilmu kebidanan, nyakit kandungan dan $\mathrm{KB}$ untuk pendidikan bidan Edisi 2. Jakarta: EGC.

Mursalim K, Masni, Tiro MA (2012). Faktor determinan pemilihan jenis persalinan dan dampaknya terhadap pemberian ASI di Rumah Sakit Kota Makassar. http://repository.unhas.ac.id:4001/digilib/files/disk1/446/kasmahmu rs-22274-1-kasmaho-29.pdf. Diakses pada 5 Juni 2016.

Murti B (2013). Desain dan ukuran sampel untuk penelitian kuantitatif dan kualitatif di bidang kesehatan: Yogyakarta. Gajah Mada University Press.

Olam S, Floranita R (2013). Materi pembelajaran kesehatan ibu dan anak. edukia: World Health Organization Country Office for Indonesia.

Prawirowihardjo S (2009). Ilmu kebidanan. Jakarta: Yayasan Bina Pustaka Sarwono Prawirowihardjo

Salfariani I, Nasution SS (2012). Faktor pemilihan persalinan sectio caesarea tanpa indikasi medis di RSU Bunda Thamrin Medan. http://jurnal.usu.co.id/. Diakses pada 21 Januari 2016.

Sarmana (2004). Determinan non medis dalam permintaan persalinan sectio caesarea di RS St. Elisabeth Medan. Fakultas Kesehatan Masyarakat Uni- 
Journal of Maternal and Child Health (2016), 1(1): 34-40

https://doi.org/10.26911/thejmch.2016.01.01.06

versitas Sumatera Utara. Diakses pada 28 Juni 2016.

Sibuea DH (2007). Manajemen seksio sesarea emergensi; masalah dan tantangan. Universitas Sumatera Utara Medan.

Szumilewicz A, Wojtyła A, Zarębska A, Kozakiewicz ID, Sawczyn M, Kwitniewska A (2013). Influence of prenatal physical activity on the course of labour and delivery according to the new polish standard for perinatal care. Annals of Agricultural and Environmental Medicine, 20(2):380-389. Diakses pada 14 Januari 2016.

Wiknjosastro GH (2009). Pelayanan kesehatan maternal dan neonatal. Jakarta: Yayasan Bina Pustaka Sarwono Prawirowiharjo.

Yudiyah D (2013). Indikasi persalinan sesar berdasarkan umur dan paritas di rumah sakit imanuel bandung. Universitas Pendidikan Indonesia. Diakses pada 5 Februari 2016. 